\title{
The Extent of Implementing the Educational Policies That Are Based on Modern Trends for Improving Technical Education in Jordanian Public Universities from the Perspective of Academic Leaders
}

\author{
Ayat Hafeth Mohammad Abu Jame’ Prof. Ahmad Mohammad Battah
}

\begin{abstract}
The present study aimed to explore the extent of implementing the educational policies that are based on modern trends for improving technical education in Jordanian public universities from the perspective of academic leaders. A descriptive developmental approach was adopted. The researchers used a questionnaire for collecting data. This questionnaire sheds a light on two areas. The researchers measured the reliability and validity of the questionnaire. The population involves all the academic leaders who were working in Jordanian public universities during the academic year (2019/2020). The stratified random sampling method was used to select a sample. The sample consists of 709 academic leaders. It was found that the extent of implementing the educational policies that are based on modern trends for improving technical education in Jordanian public universities is moderate from the perspective of academic leaders in two areas. These areas are: (educational policies and technical education). It was found that there isn't any statistically significant difference -at the statistical significance level of $(a=0.05)$ between the respondents' attitudes which can be attributed to job title or year of experience. It was found that there is a statistically significant difference -at the statistical significance level of $(a=0.05)$ - between the respondents' attitudes which can be attributed to university. The latter difference is for the favor of the ones who work in the universities located in the Central Province. The researchers recommend promoting awareness among managers of the top management levels in public universities about the need for developing the educational policies that aim at improving technical education
\end{abstract}

Keywords: Educational policies, technical educational programs, modern trends related to technical education, Jordanian public universities.

DOI: $10.7176 / \mathrm{JEP} / 11-19-11$

Publication date:July $31^{\text {st }} 2020$

\section{Introduction}

Education aims at achieving development in various areas. Such areas include: economic and social areas. Today, it is necessary to develop human capital in order to achieve development. To be specific, achieving development requires having people who are highly educated, skillful and productive. Having such people shall contribute to the development of society.

In this regard, it should be noted that technical education has been developing. Such education plays a significant role in achieving development in various areas. For instance, it plays a significant role in fighting against unemployment, and raising people's income. It also plays a significant role in improving people's living conditions and making social reforms in society. It plays a significant role in training and developing people and providing them with expertise. It enables people to join the labor market. The provision of technical education provides the labor market with professionals in various majors.

During the last couple of decades, the Arab World has been experiencing various dramatic changes in the educational field. These changes affected various educational stages. It should be noted that much attention has been provided to technical education. However, the delivery of technical education requires meeting several requirements and exerting much efforts. It also requires dedicating much funds. It requires developing special curricula. It requires taking the demands of the labor of market into consideration (Al-Zawba'i and Al-Janabi, 2017).

The most significant challenge that have been facing technical education is represented in the low number of the ones joining technical educational programs. That is because young people perceive technical education as being less prestigious than academic education. It is because young people perceive technical education as the only option for the ones who aren't capable of enrolling in a university. In order to change people's stereotypical views about technical education, there must be changes made to technical educational programs. Such changes must aim at providing the ones receiving technical education with the required knowledge, skills, expertise and training. That shall increase the number of the job opportunities that are available to the ones receiving technical education. It shall expand their knowledge. It shall make them establish a successful career.

Due to the significance of technical education, many developed and developing countries have been providing attention to such education. Such attention has been also provided by the governments of Arab countries. For instance, technical education plays a significant role in achieving scientific and technological advancement. 
The attention provided for technical education is represented in making qualitative and quantitative achievements in this field (Gomes and Brizuela, 2011).

Technical education has been delivered recently in Arab countries. Therefore, it is still developing in Arab countries. The extent of developing technical education in Arab countries varies from one Arab country to another. Technical education has a special nature that differs from the nature of primary, school and university education. During the last two decades, major developments have occurred to technical education. It should be noted that the nature of technical education is determined by the social and economic conditions of the society. In addition, such nature is determined by the degree to which the society is developed in technological areas.

Technical education aims to meet the demands of the labor market. It aims to meet such demands through providing the labor market with labor force that contributes to achieving development in society. Such labor force contributes to achieving development in society through working in industrial, agricultural, health, service and other institutions (Abu Zainah, 2011).

In Jordan, several developments have been occurring to the technical educational field during the last couple of decades. For instance, several vocational schools, and community colleges have been established in Jordan recently. These schools, and community colleges offer vocational programs in various areas. These programs keep up with the latest developments in the economic, production, and service fields.

In Jordan, the technical educational field has been playing a significant role in achieving development in Jordan. Therefore, technical educational issues have been addressed much through development plans in Jordan. Such plans include: the National Agenda and the Program of Implementing the National Strategy of Recruitment and Training. In Jordan, the technical educational field has been receiving much attention by international technical institutions that offer grants. Such attention contributed to the improvement of the administrative and technical capabilities of the labor force (The Economic and Social Council, 2017).

In Jordan, there has been a decline in the performance of the educational system. Such decline led to the decline in the quality of education in Jordan. It led to having inconsistency between the outcomes of the educational institutions and the demands of the labor market. It led to having a decline in the qualification level of the staff in educational institutions. Such staff include: instructors, principals and academic supervisors. The decline in the performance of the educational system led to having curricula that don't promote awareness about human rights nor meet the latest requirements. Due to the decline in the performance of the educational system in Jordan, a royal commission was formed. The latter commission aimed at developing a national strategy for developing human resources. It aimed to develop a plan for making reforms to the educational system (Al-Btoush, 2019).

Although major achievements have been made in Jordan in the fields of vocational and technical education. Such achievements include qualitative and quantitative achievements. However, there are many problems and challenges facing vocational and technical education. Such problems and challenges negatively affect the qualitative and quantitative achievements of the vocational and technical education. Such challenges include: the low number of the ones joining technical educational programs in comparison to the number of the ones joining academic programs. They include the inconsistency between the outcomes of technical educational institutions and the demand of the labor market. They include: the lack of the contributions of the private sector in the delivery of technical educational services. They include: the lack of attention provided by media to technical education. They include: possessing inadequate information by educational institutions about the demands of the labor market. The latter inadequacy is attributed to the employment of ineffective data collection methods. It is attributed to the poor contribution of the private sector in the technical educational fields (The Jordanian Ministry of Education, 2012).

To provide support for technical education in Jordan, Al-Hussein Technical University was established in Jordan. The latter university is considered the biggest institution in Jordan that delivers technical education. It seeks offering majors that are associated with great job prospects and much demand in the labor market. It seeks meeting the vision of Prince Hussein bin Abdullah II in order to serve the Jordanian youth. It aims at developing Jordanian youth in in order to improve their future. It aims at create a better future for Jordan. It aims to meet these goals through improving the quality of higher education and technical education. It aims to meet these goals through achieving consistency between the technical education programs and the needs of the Jordanian society. It aims to meet these goals in order to achieve sustainable development in Jordan (Al-Btoush, 2019).

It has been suggested that there is a need for conducting more educational studies about the urgent need for developing technical educational policies. There's also a need for conducting studies about the urgent need for achieving consistency between the outcomes of vocational educational institutions and the demand of the labor market (Bashyawa, 2013).

Since the beginning of the third millennium, there have been major rapid changes in various fields worldwide. The latter changes are attributed to the expansion of people's knowledge and the increase of the number of the ones holding postgraduate degrees. They are attributed to having major scientific developments and inventions in all the areas, especially the ICT area. They are attributed to information revolution. That latter revolution facilitated the way people connect with each other and enabled people to overcome the spatial limitations. Thus, it 
strengthened the social bonds between people. It turned the world into a small village. Due to the information revolution, information and knowledge become the source of power. They have been playing a significant role in achieving development and growth in societies. Since the beginning of the third millennium, there have been several international and regional political, economic, and social changes (Abu Qaren, 2012).

There has been a decline in the effectiveness of educational policies in Jordan. According to Battah (2018), such decline is attributed to several reasons. Such reasons include: the migration of 300,000 Palestinians from Kuwait to Jordan due to the invasion of Kuwait by Iraq. They include: the migration of many Iraqi people from Iraq to Jordan due to invasion of Iraq by the United States. Thus, classrooms in Jordan became crowded. That serves as a challenge facing the Ministry of Education in Jordan. The stand of the Jordanian government on the Gulf crisis wasn't accepted by the governments of the Western and Gulf countries. That led to decreasing the amount of grants and aids given to the Jordanian government. Such decrease negatively affected the performance of the Ministry of Education in Jordan. It hindered the latter ministry from establishing new schools, and developing the staff in educational institutions. It negatively influenced the educational process. There are other reasons behind the decline in the effectiveness of educational policies in Jordan.

\section{Previous Studies}

The researchers of the present study reviewed several studies. These studies are presented below based on the year of publication. They are presented below from the oldest to the newest:

Al-Twaisi (2013) aimed to identify the types of the solutions that are proposed for improving people's perceptions towards technical and vocational education and training (TVET) in Jordan. He aimed to identify that from the perspective of experts in Jordan. The population involves all the experts in the policies of the technical and vocational education and training (TVET) in Jordan. The sample consists of 167 experts. It was fond that the latter solutions include the following types of solutions: 1)-solutions related to curricula and training methods, 2)solutions related to infrastructure, and educational environment, 3)- solutions related to policies and legislations 4)- solutions related to media and communication methods, and 5)- solutions related to the programs that aim at promoting awareness about the significance of technical and vocational education among the concerned officials.

Nillitaru et al. (2015) aimed to explore the role of technical entrepreneurship in promoting entrepreneurship among the students enrolled in the technical universities. A descriptive survey-based approach was adopted. The sample consists of 280 students who were enrolled in the entrepreneurship faculty of Politehnica University in Bucharest. The latter researchers developed a questionnaire to collect the required data. It was found that there isn't any statically significant difference between the respondents' attitudes which can be attributed to any of the study's variables. It was found that entrepreneurship education contributes the acquisition of entrepreneurship skills and improvement of the capability to utilize entrepreneurial opportunities. Having this capability requires having excellent capability in using technology. It requires promoting a culture of entrepreneurship among students. The latter researchers recommend conducting more studies about technical entrepreneurship.

Abu Al-Rab (2017) aimed to develop a vision for improving the technical education delivered by Palestinian universities. He aimed to develop this vision based on the contemporary experiences of universities in other countries. He aimed to explore the current and future reality of technical education in Palestinian universities from the perspective of academic leaders. He used a questionnaire to collect data and develop the vision. He adopted a descriptive developmental approach. The study's population consists of 200 leaders. It was found that academic leaders have moderate attitudes towards the reality of technical education in Palestinian universities. It was found that the development of technical education in Palestinian universities is significant. It was found that there isn't any statistically significant difference -at the statistical significance level of $(a \leq 0.05)$ - between the respondents' attitudes which can be attributed to experience or job title. It was found that there is a statistically significant difference -at the statistical significance level of $(a \leq 0.05)$ - between the respondents' attitudes which can be attributed to university. The latter researcher developed a vision for improving the technical education delivered by Palestinian universities. He recommends implementing the proposed vision because it is flexible and applicable.

Abdullah (2017) aimed to develop a vision for developing technical and vocational education in Libya. He adopted a descriptive analytical approach. The sample consists of 230 teachers and trainers. Those teachers and trainers were selected from the institutes, colleges and centres delivering technical and vocational education in Libya. The latter researcher developed a questionnaire for collecting data. It was found that the efficiency of technical and vocational educational programs in Libya is low. It was found that that the number of students who join these programs in Libya is low. It was found that the number of teachers in technical and vocational educational schools is low. It was found that the technical and vocational educational centres and institutions have a poor infrastructure that doesn't meet global standard.

Abed Al-Ghani and Abed Al-Qader (2017) aimed to explore the reality of technical education in Sudan. A descriptive analytical approach was adopted. The sample consists of 100 teachers and 100 individuals who graduated from technical colleges. The latter researchers used a questionnaire for collecting data. It was found that the salaries of the staff in technical educational institutions are low. Such salaries don't enable the staff to meet 
their needs. It was found that the number of the staff in technical educational institutions isn't adequate. The latter researchers recommend conducting more studies about technical education in Libya

Barba-Sánchez, \& Atienza- Sahuquillo (2018) aimed to explore the role of entrepreneurship education in promoting entrepreneurship and a sense of initiative among the students majoring in computer engineering and the students majoring in industrial engineering in Castilla - La Mancha's University in Spain. A descriptive analytical approach was adopted. The sample consists of 423 students majoring in computer engineering and students majoring in industrial engineering. A questionnaire was used for collecting data. It was found that need for independency is one of the main reasons behind practicing entrepreneurship and learning about it. It was found that there isn't any significant difference between the respondents' attitudes which can be attributed to university.

Harfoosh and Harfoosh (2019) aimed to explore the role of Palestinian principals in promoting positive attitudes among school students towards technical and vocational education. A descriptive analytical approach was adopted. The sample consists of 800 students who were selected randomly. Questionnaire forms were distributed to those students. The questionnaire consists of 30 items. It was found that the role of Palestinian principals in promoting positive attitudes among school students towards technical and vocational education is moderate. It was found that there isn't any statistically significant difference between the respondents' attitudes which can be attributed to gender. The latter researchers suggest that school managements should use school activities for promoting positive attitudes among school students towards technical and vocational education. They suggest that school managements should utilize the school morning assembly, school bulletin board and voluntarily works to promote such attitudes among students. They recommend holding workshops for students to promote such attitudes among them.

Al-Sahli (2019) aimed to explore the reality of the policies of education, scientific research and community service in Saudi universities. He adopted a descriptive survey-based approach. He developed a questionnaire for collecting data. The study's population involves all the faculty members who hold $\mathrm{PhD}$ degrees and work in Saudi universities. The latter researcher selected a random sample from King Saud University and King Abdul-Aziz University. This sample consists of 302 faculty members. It was found that the reality of the policies of education, scientific research and community service in Saudi universities is moderate. The latter researcher developed a strategy for developing the educational policies implemented in Saudi universities. The latter strategy meets the requirements of competitiveness.

Al-Qarni (2019) aimed to explore the reality of technical and vocational educational programs in the vocational training centres in Reyad, Saudi Arabia. She aimed to explore that from the perspective of academic leaders who are specialized in technical and vocational education. She used a survey to collect data. The survey consists of 25 items. It sheds a light on four areas. These areas include: 1)-Assessment of learning and training conditions at the vocational training centres, 2)- requirements of transition, and work, 3)- recruitment , and 4)vocational guidance and job satisfaction. The sample consists of 869 female and male individuals. It was found that the mean of the (recruitment) area is ranked first. The mean of the (assessment of learning and training conditions at the centres) is ranked second. The mean of the (vocational guidance and job satisfaction) is ranked last. It was found that there is a statistically significant difference between the respondents' attitudes which can be attributed to gender in all the study's areas. The latter difference is for the favour of the female respondents. It was found that there is a statistically significant difference between the respondents' attitudes which can be attributed to job title in all the study's areas. The latter difference is for the favour of the academic leaders who are specialized in vocational education. It was found that there isn't any statistically significant difference between the respondents' attitudes which can be attributed to experience. The latter researcher recommends developing vocational guidance programs in vocational training centres in order to increase the job opportunities of students.

After reviewing the relevant studies, it was found that there aren't many studies that shed a light on the educational policies that are based on modern trends for improving technical education. Hence, the present study aimed to explore the extent of implementing the educational policies that are based on modern trends for improving technical education in Jordanian public universities

\section{Statement of the problem and the study's questions}

In the past, technical education didn't receive much attention. It was associated with academic failure, low income and low social status. It wasn't provided with adequate attention by governments, and international institutions and organizations. In fact, plan makers started recently to realize the significance of technical education. Based on several studies (e.g. the study of Abu Zainah (2011), the demands of the labor market have been significantly changing during the last two decades. Due to such change, the labor force are in need for developing their skills and capabilities. Due to such change, the technical educational institutions must provide the labor market with individuals who possess excellent technical skills, and capabilities that enable them to practice their profession professionally.

Al-Mutairi et al. (2019) found that technical education plays a moderate role in achieving development in Jordan from the experts' perspective. Thus, educational experts and decision makes must make changes to 
technical education in universities. Hence, there is a need to explore the extent of implementing the educational policies that are based on modern trends for improving technical education in Jordanian universities. Therefore, the present study aimed to explore that in Jordanian public universities. To be specific, it aimed to offer answers to the following questions:

Q.1. What is the extent of implementing the educational policies that are based on modern trends for improving technical education in Jordanian public universities from the perspective of academic leaders?

Q.2. Is there any statistically significant difference -at the statistical significance level of $(a=0.05)$ - between the respondents' attitudes which can be attributed to (university, job title, or experience)?

\section{The Study's Objectives}

The present study aimed to explore the extent of implementing the educational policies that are based on modern trends for improving technical education in Jordanian public universities from the perspective of academic leaders. It aimed to identify whether there is any statistically significant difference - at the statistical significance level of $(\mathrm{a}=0.05)$ - between the respondents' attitudes which can be attributed to (university, job title, or experience).

\section{The Study's Significance}

-Practical significance: The present study is significant because it provides decision makers in Jordanian public universities with beneficial information about the educational policies that are suitable for improving effective technical education in a manner that fits with reality. It is significant because it provides the makers of educational plans with beneficial information that can improve the quality of technical education.

-Theoretical significance: The present study is significant because it enriches the literature that's related to technical education. It is significance because it encourages researchers to conduct more studies about this subject. That shall contribute to enriching the relevant literature

\section{Definition of Terms}

\section{The study's terms are defined below:}

- Educational policy (theoretical definition): It refers to general guidelines that the educational process should be based on. Adhering to such guidelines contributes to meeting the society's needs, and goals. It regulates issues related to several educational stages and fields. It regulates issues related to educational plans, curricula, and methods. It regulates issues related to administrative systems and devices used for delivering education. It aims at providing the society with good citizens who are highly qualified in intellectual and scientific areas (Al-Suheimat, 2003).

Educational policy includes several educational principles and directions that are set by educational bodies. It aims at guiding educators in the way of delivering education. It serves as the basis of the educational process. It is derived from the state's national policy. It is derived from the dominant ideology and philosophy in society (Battah, 2020).

Educational policy (operational definition): It includes several rules and foundations that aim at improving the reality of education. These rules and foundations are derived from the educational approach that is adopted by the academic leaders in the university.

Technical education: (theoretical definition): It is delivered during the secondary school stage. It aims to provide the labor market with qualified technicians in various economic sectors. It seeks providing students with the required skills and knowledge (Abed Al-Ghani and Abed Al-Qader, 2017).

The United Nations Educational, Scientific and Cultural Organization (UNESCO) (2009) suggests that vocational education involves several types of education. It adds that vocational education may be related to technology, applied sciences, agriculture, business, industry, or visual art. It adds that vocational education aims at developing individuals and providing them with knowledge and skills. It aims at enabling people to join the labour market. -Technical education (operational definition): It aims at adjusting one's behaviour and educating him/her. It provides one with technical skills that enable him/her to join the labour market. After receiving technical education, one shall get a certificate.

Academic leaders: They refer to the leaders who are capable to influence others in order to make them do the required tasks. They aim at coordinating people's efforts in order to meet the intended goals. They include: presidents, deans and heads of departments (Zeedan, 2012).

Academic leaders (operational definition): They refer to the academics who must do administrative tasks. They include: deans, vice deans, and heads of departments in Jordanian universities.

\section{The Study's Limits:}

The study's limits are presented below:

- Temporal limits: The present study was conducted during the academic year (2019/2020)

- Spatial limits: The present study was conducted in several Jordanian public universities 
- Human limits: The researchers selected a sample that consist from several academic leaders who work in Jordanian public universities. Those academic leaders include: deans, vice deans and heads of departments.

\section{The Study's Procedures}

This part identifies the study's approach, population, sampling method, data collection methods, and procedures. It identifies the validity and reliability of the instrument. It identifies the statistical analysis methods.

\subsection{Approach}

The researchers adopted a descriptive developmental approach. They used a questionnaire to collect data. They measured the validity and reliability of the questionnaire. The questionnaire sheds a light on several areas.

\subsection{Population}

The study's population is represented in all the academic leaders who were working in Jordanian public universities during the academic year (2019/2020). It consists of 945 academic leaders.

\subsection{Sample}

The researchers selected the sample through using the stratified random sampling method. Based on the sample size table of Sekran (2003), they selected a sample that consists of 709 academic leaders. Those academic leaders were selected from six public universities; the University of Jordan, Balqa Applied University, Yarmook University, Jordan University of Science and Technology, Mu'tah University, and Tafila Technical University. Questionnaire forms were distributed to the selected leaders. 694 questionnaire forms were retrieved. Table (1) presents the distribution of the study's sample in accordance with job title, university and experience.

Table (1): The distribution of the study's sample in accordance with job title, university and experience

\begin{tabular}{|l|l|l|}
\hline Variable & Category & Frequency \\
\hline \multirow{5}{*}{ Job title } & Dean & 82 \\
\cline { 2 - 3 } & Vice dean & 130 \\
\cline { 2 - 3 } & Dean assistant & 128 \\
\cline { 2 - 3 } & Heads of departments & 354 \\
\hline \multirow{3}{*}{ University } & Universities located in the Northern province & 224 \\
\cline { 2 - 3 } & Universities located in the Central province & 355 \\
\cline { 2 - 3 } & Universities located in the Southern province & 115 \\
\hline \multirow{2}{*}{ Experience } & Less than 5 years of experience & 331 \\
\cline { 2 - 3 } & 5 years -less than 10 years & 158 \\
\cline { 2 - 3 } & 10 years - less than 15 years & 121 \\
\cline { 2 - 3 } & 15 years or more & 84 \\
\hline
\end{tabular}

\subsection{The Study's Instrument}

To meet the study's goals, the researchers developed a questionnaire. This questionnaire aims to explore the extent of implementing the educational policies that are based on modern trends for improving technical education in Jordanian public universities from the perspective of academic leaders. It was developed based on several studies, such as: the studies that were conducted by: Bashyawa (2013), Abu Zainah (2008) and Nillitaru et al. (2015).

\subsection{The content validity of the Instrument:}

To measure the questionnaire's content validity, the researchers passed the questionnaire to eight (8) experts. Those experts include: experts in educational administration, experts in instructional technology, and experts in measurement and assessment. Those experts were selected from several Jordanian public universities. They suggested that the questionnaire is a reliable data collection instrument.

\subsection{The structural Validity of the instrument:}

The structural validity of the instrument was measured through calculating the correlation coefficient values. Each correlation coefficient value represents the extent of relevancy between an item and the area it belongs to. The correlation coefficient values are within the range of $(0.856-0.736)$. They are statistically significant values and accepted. Thus, none of the items were deleted.

\subsection{Reliability of the Instrument:}

To measure the reliability of the questionnaire, the researchers distributed the questionnaire forms to an exploratory sample. This exploratory sample consists of 40 individuals. After that, the reliability of the instrument was 
measured through using the test-re-test method. Through this method, Pearson correlation coefficient values were calculated. These values are presented in table (2). The researchers also measured the reliability of the instrument through calculating the Cronbach Alpha coefficient values. The latter values are presented in table (2) below. The Pearson correlation coefficient values and the Cronbach Alpha coefficient values indicate that the instrument is very reliable.

Table (2): The Pearson correlation coefficient and the Cronbach Alpha coefficient values

\begin{tabular}{|l|r|r|}
\hline Area & The Pearson correlation coefficient & \multicolumn{2}{|l|}{ Cronbach Alpha coefficient values } \\
\hline Educational policies & 0.94 & 0.88 \\
\hline Technical education & 0.97 & 0.92 \\
\hline
\end{tabular}

\subsection{The Study's Variables:}

The study's variables are presented below:

-Independent variable: They include: the (university, job titled and years of experience) of the respondents.

-Dependent variables: It's represented in the respondents' attitudes.

\subsection{Classification of the means:}

The present study aimed to explore the extent of implementing the educational policies that are based on modern trends for improving technical education in Jordanian public universities from the perspective of academic leaders. The five point Likert scale was adopted. It consists of five rating categories. These categories are: (to a very great extent, to a great extent, to a moderate extent, to a small extent, and to a very small extent). They stand for the following scores respectively; 5, 4, 3,2 and 1. The means are classified into: low, moderate and high means based on specific criteria. The following criteria are adopted for classifying means:

2.33 or less: low

2.34- 3.67: Moderate

3.68 or more: High

\section{The Study's Results:}

This part presents the study's results. After analyzing the collected data statistically, results were reached. They are presented below

First: Results related to the first question:

Q.1. What is the extent of implementing the educational policies that are based on modern trends for improving technical education in Jordanian public universities from the perspective of academic leaders?

To answer this question, means and standard deviations are calculated. Table (3) presents these values below:

Table (3): The means and standard deviations of the extent of implementing the educational policies that are based on modern trends for improving technical education in Jordanian public universities from the perspective of academic leaders

\begin{tabular}{|l|l|l|l|l|l|}
\hline No. & Area & Mean & Std. & Rank & Level \\
\hline 2 & Technical education & $\mathbf{2 . 4 5}$ & 0.78 & 1 & Moderate \\
\hline 1 & Educational policies & $\mathbf{2 . 3 8}$ & 0.78 & 2 & Moderate \\
\hline & Total & 2.41 & 0.75 & & Moderate \\
\hline
\end{tabular}

Based on table (3), the mean of the (technical education) area is ranked first. It is 2.45 . The mean of the (educational policies) area is ranked second. It is 2.38. The standard deviation and mean of each item is calculated. The detailed results of each area are presented below.

The first area: Educational policies

To explore the respondents' attitudes, means and standard deviations are calculated. They are presented in table (4) below.

Table (4): Means and standard deviations of the statements related to educational policies

\begin{tabular}{|r|l|r|r|r|r|}
\hline No. & Area & Mean & Std. & Rank & Level \\
\hline $\mathbf{1}$ & $\begin{array}{l}\text { The university seeks assessing performance through developing } \\
\text { accreditation regulations. That is done to deliver university } \\
\text { education of high quality }\end{array}$ & 2.53 & 1.16 & 1 & Moderate \\
\hline $\mathbf{2 0}$ & $\begin{array}{l}\text { Public universities provide the resources needed for having a secure } \\
\text { learning environment that fits with the relevant occupational health } \\
\text { and safety regulations }\end{array}$ & 2.47 & 1.13 & 2 & Moderate \\
\hline $\mathbf{2}$ & Academic leaders in the university develop visions & 2.47 & 1.19 & 3 & Moderate \\
\hline $\mathbf{1 1}$ & $\begin{array}{l}\text { The university develops educational strategies and implements the } \\
\text { modern educational policies }\end{array}$ & 2.44 & 1.16 & 4 & Moderate \\
\hline
\end{tabular}




\begin{tabular}{|c|c|c|c|c|c|}
\hline No. & Area & Mean & Std. & Rank & Level \\
\hline 16 & $\begin{array}{l}\text { The educational policies of the university aim at achieving } \\
\text { alignment between the educational approaches in order to provide } \\
\text { society with qualified labour force. }\end{array}$ & 2.43 & 1.13 & 5 & Moderate \\
\hline 6 & $\begin{array}{r}\text { The educational policies of the university regulates the educational } \\
\text { process }\end{array}$ & 2.41 & 1.18 & 6 & Moderate \\
\hline 13 & $\begin{array}{l}\text { The university seeks developing its educational policies in an } \\
\text { ongoing manner. That is because educational policies play a } \\
\text { significant role in choosing the educational approaches }\end{array}$ & 2.41 & 1.14 & 6 & Moderate \\
\hline 10 & $\begin{array}{l}\text { The educational policies of the university include the educational } \\
\text { goals that are related to the knowledge of the society's members }\end{array}$ & 2.40 & 1.09 & 8 & Moderate \\
\hline 5 & $\begin{array}{l}\text { The educational policies of the university govern the process of } \\
\text { framing the educational regulations developed by the academic } \\
\text { leaders of the university }\end{array}$ & 2.40 & 1.10 & 8 & Moderate \\
\hline 17 & $\begin{array}{l}\text { Due to the presence of information technology, the university } \\
\text { implements educational policies that aim at providing students with } \\
\text { excellent skills in using technology }\end{array}$ & 2.40 & 1.13 & 8 & Moderate \\
\hline 19 & $\begin{array}{l}\text { Public universities seek adhering to educational regulations in order } \\
\text { to promote transparency }\end{array}$ & 2.39 & 1.10 & 11 & Moderate \\
\hline 4 & $\begin{array}{l}\text { The vision of the educational leaders at the university includes } \\
\text { developing and exchanging knowledge }\end{array}$ & 2.38 & 1.14 & 12 & Moderate \\
\hline 18 & $\begin{array}{l}\text { Public universities assess the effectiveness of their policies in order } \\
\text { to deliver education of high quality }\end{array}$ & 2.36 & 1.18 & 13 & Moderate \\
\hline 3 & $\begin{array}{l}\text { The educational policies of the university have a positive impact on } \\
\text { the educational processes carried out at it. That is because these } \\
\text { policies aim at implementing programs that produce knowledge } \\
\text { products }\end{array}$ & 2.35 & 1.12 & 14 & Moderate \\
\hline 8 & $\begin{array}{l}\text { The educational policies of the university aim at developing the } \\
\text { society }\end{array}$ & 2.34 & 1.19 & 15 & Moderate \\
\hline 12 & $\begin{array}{l}\text { The educational strategies of the public technical universities aims } \\
\text { at developing effective educational programs }\end{array}$ & 2.33 & 1.16 & 16 & Moderate \\
\hline 14 & $\begin{array}{l}\text { The educational policies of the university aim at conducting studies } \\
\text { that address several issues that matter for the members of the society }\end{array}$ & 2.33 & 1.11 & 16 & Moderate \\
\hline 15 & $\begin{array}{l}\text { The educational policies of the university fit with the developmental } \\
\text { plans of the university }\end{array}$ & 2.30 & 1.14 & 18 & Moderate \\
\hline 9 & $\begin{array}{l}\text { The educational policies of the university serve as the pillar of the } \\
\text { educational process and achievements made in society }\end{array}$ & 2.26 & 1.16 & 19 & Moderate \\
\hline & $\begin{array}{l}\text { The educational policies of the university fit with the dominant } \\
\text { philosophy of the society }\end{array}$ & 2.25 & 1.11 & 20 & Moderate \\
\hline & $\begin{array}{ll}2 & \text { Overall } \\
\end{array}$ & 2.38 & 0.78 & & Moderate \\
\hline
\end{tabular}

Based on table (4), the means are within the range of 2.53-2.25. The mean of statement 1 is ranked 2.53 which is ranked first. The standard deviation of the latter statement is 1.65 . The latter statement states the following: "'The university seeks assessing performance through developing accreditation regulations. That is done to deliver university education of high quality'. The mean of statement 7 is ranked 2.25 which is ranked last. The standard deviation of the latter statement is 1.19. The latter statement states the following: "The educational policies of the university fit with the dominant philosophy of the society'". The mean of the (educational policies) area is 2.38 . The standard deviation of the latter area is 0.78 .

The second area: Technical education

To explore the results related to the second area, means and standard deviations were calculated. They are presented in table (5) below

Table (5): Means and standard deviations of the statements related to technical education

\begin{tabular}{|r|l|r|r|r|r|}
\hline No. & Area & Mean & Std. & Rank & Level \\
\hline $\mathbf{3 0}$ & $\begin{array}{l}\text { The public technical universities seek providing a convenient } \\
\text { learning environment for the delivery of technical education }\end{array}$ & 2.56 & 1.11 & 1 & Moderate \\
\hline $\mathbf{3 6}$ & $\begin{array}{l}\text { The public technical universities make a special budget for } \\
\text { supporting their technical educational projects }\end{array}$ & 2.56 & 1.08 & 1 & Moderate \\
\hline $\mathbf{2 3}$ & $\begin{array}{l}\text { The public universities consider the promotion of a technical } \\
\text { entrepreneurship as an essential part of their educational mission }\end{array}$ & 2.52 & 1.13 & 3 & Moderate \\
\hline
\end{tabular}




\begin{tabular}{|c|c|c|c|c|c|}
\hline No. & Area & Mean & Std. & Rank & Level \\
\hline 31 & $\begin{array}{l}\text { The public universities provide each (faculty, department and unit) } \\
\text { with independency to promote technical entrepreneurship }\end{array}$ & 2.49 & 1.14 & 4 & Moderate \\
\hline 21 & $\begin{array}{l}\text { The presence of information technology significantly affects the } \\
\text { alternatives for university education }\end{array}$ & 2.48 & 1.13 & 5 & Moderate \\
\hline 22 & $\begin{array}{l}\text { Media institutions seek encouraging people to enroll in technical } \\
\text { educational programs in public universities }\end{array}$ & 2.48 & 1.16 & 5 & Moderate \\
\hline 32 & $\begin{array}{l}\text { Public universities are keen on ensuring that technical entrepreneur } \\
\text { are provided with the required guidance by business entrepreneur }\end{array}$ & 2.47 & 1.13 & 7 & Moderate \\
\hline 28 & $\begin{array}{l}\text { Academics in public technical universities use a variety of teaching } \\
\text { methods for delivering technical education }\end{array}$ & 2.46 & 1.14 & 8 & Moderate \\
\hline 37 & $\begin{array}{l}\text { Public technical universities seek practicing productive } \\
\text { entrepreneurship in order to have additional sources of funding }\end{array}$ & 2.45 & 1.18 & 9 & Moderate \\
\hline 40 & $\begin{array}{l}\text { Public technical universities are keen on ensuring that their curricula } \\
\text { address theoretical and practical issues }\end{array}$ & 2.45 & 1.17 & 9 & Moderate \\
\hline 39 & $\begin{array}{l}\text { Public technical universities encourage students to conduct } \\
\text { theoretical and empirical research on technical works. }\end{array}$ & 2.45 & 1.17 & 9 & Moderate \\
\hline 35 & $\begin{array}{l}\text { Public technical universities are keen on attracting students whose } \\
\text { academic achievement in Tawjihi is excellent }\end{array}$ & 2.44 & 1.10 & 12 & Moderate \\
\hline 34 & $\begin{array}{l}\text { Public universities provide (technical and administrative) support } \\
\text { for students in order to turn their ideas into successful projects }\end{array}$ & 2.44 & 1.16 & 12 & Moderate \\
\hline 33 & $\begin{array}{l}\text { Public universities seek recruiting faculty members who possess } \\
\text { technical skills }\end{array}$ & 2.44 & 1.16 & 12 & Moderate \\
\hline 24 & $\begin{array}{l}\text { Public universities develop effective criteria for recruiting academic } \\
\text { leaders who possess leadership skills }\end{array}$ & 2.43 & 1.14 & 15 & Moderate \\
\hline 27 & $\begin{array}{l}\text { The goals of technical education in public universities are } \\
\text { meaningful }\end{array}$ & 2.42 & 1.12 & 16 & Moderate \\
\hline 29 & $\begin{array}{l}\text { The curricula used for delivering technical education in public } \\
\text { universities anticipate a promising future for technical education }\end{array}$ & 2.39 & 1.14 & 17 & Moderate \\
\hline 25 & $\begin{array}{l}\text { Technical education in public universities keeps up with the latest } \\
\text { technological developments }\end{array}$ & 2.39 & 1.15 & 17 & Moderate \\
\hline 26 & $\begin{array}{l}\text { The curricula used for delivering technical education emphasize the } \\
\text { significance of providing training to students in public universities }\end{array}$ & 2.38 & 1.17 & 19 & Moderate \\
\hline \multirow[t]{2}{*}{38} & $\begin{array}{l}\text { Technical universities provide their students with field learning } \\
\text { opportunities through cooperating with institutions in various } \\
\text { sectors }\end{array}$ & 2.38 & 1.13 & 19 & Moderate \\
\hline & Overall & 2.45 & 0.78 & & Moderate \\
\hline
\end{tabular}

Based on table (5), the means are within the range of (2.56-2.38). The mean of statement 30 is ranked 2.56 which is ranked first. The standard deviation of the latter statement is 1.11 . The latter statement states the following:

"Public technical universities seek providing a convenient learning environment for the delivery of technical education". The mean of statement 38 is ranked 2.38 which is ranked last. The standard deviation of the latter statement is 1.139. The latter statement states the following: "Technical universities provide their students with field learning opportunities through cooperating with institutions in various sectors'. The mean of the (technical education) area is 2.45 . The standard deviation of the latter area is 0.78 .

Results related to the second question:

Q.2. Is there any statistically significant difference -at the statistical significance level of $(\mathrm{a}=0.05)-$ between the respondents' attitudes which can be attributed to (university, job title, or experience)?

Means and standard deviation are calculated to identify the respondents' attitudes in accordance with their (university, job title, and experience). Those means and standard deviations are presented in table (6) below. To identify whether the differences between their attitudes are statistically significant or not, the multivariate analysis of variance (MANOVA) was conducted. 
Table (6): Means and standard deviation to identify the respondents' attitudes in accordance with their (university, job title, and experience)

\begin{tabular}{|c|c|c|c|c|c|}
\hline Variable & Category & Frequency & $\begin{array}{l}\text { Arithmetic mean and } \\
\text { standard deviation }\end{array}$ & $\begin{array}{l}\text { Educational } \\
\text { policies }\end{array}$ & $\begin{array}{l}\text { Technical } \\
\text { education }\end{array}$ \\
\hline \multirow[t]{8}{*}{ University } & \multirow{2}{*}{$\begin{array}{l}\text { Universities located in } \\
\text { the Central province }\end{array}$} & \multirow[t]{2}{*}{355} & Arithmetic mean & 2.65 & 2.79 \\
\hline & & & Standard deviation & 0.97 & 0.93 \\
\hline & \multirow{2}{*}{$\begin{array}{l}\text { Universities located in } \\
\text { the Southern province }\end{array}$} & \multirow[t]{2}{*}{115} & Arithmetic mean & 2.02 & 2.08 \\
\hline & & & Standard deviation & 0.24 & 0.30 \\
\hline & \multirow{2}{*}{$\begin{array}{l}\text { Universities located in } \\
\text { the Northern province }\end{array}$} & \multirow[t]{2}{*}{224} & Arithmetic mean & 2.12 & 2.10 \\
\hline & & & Standard deviation & 0.30 & 0.31 \\
\hline & \multirow[t]{2}{*}{ Overall } & \multirow[t]{2}{*}{694} & Arithmetic mean & 2.38 & 2.45 \\
\hline & & & Standard deviation & 0.78 & 0.78 \\
\hline \multirow[t]{10}{*}{ Job title } & \multirow[t]{2}{*}{ Dean } & \multirow[t]{2}{*}{82} & Arithmetic mean & 2.32 & 2.41 \\
\hline & & & Standard deviation & 0.85 & 0.83 \\
\hline & \multirow[t]{2}{*}{ Vice dean } & \multirow[t]{2}{*}{130} & Arithmetic mean & 2.65 & 2.75 \\
\hline & & & Standard deviation & 0.95 & 0.95 \\
\hline & \multirow[t]{2}{*}{ Dean assistant } & \multirow[t]{2}{*}{128} & Arithmetic mean & 2.56 & 2.59 \\
\hline & & & Standard deviation & 0.88 & 0.90 \\
\hline & \multirow[t]{2}{*}{ Head of department } & \multirow[t]{2}{*}{354} & Arithmetic mean & 2.22 & 2.30 \\
\hline & & & Standard deviation & 0.59 & 0.59 \\
\hline & \multirow[t]{2}{*}{ Overall } & \multirow[t]{2}{*}{694} & Arithmetic mean & 2.38 & 2.45 \\
\hline & & & Standard deviation & 0.78 & 0.78 \\
\hline \multirow[t]{10}{*}{ Experience } & \multirow{2}{*}{$\begin{array}{c}\text { Less than } 5 \text { years of } \\
\text { experience }\end{array}$} & \multirow[t]{2}{*}{331} & Arithmetic mean & 2.19 & 2.26 \\
\hline & & & Standard deviation & 0.56 & 0.57 \\
\hline & \multirow{2}{*}{$\begin{array}{r}5 \text { years -less than } 10 \\
\text { years }\end{array}$} & \multirow[t]{2}{*}{158} & Arithmetic mean & 2.57 & 2.61 \\
\hline & & & Standard deviation & 0.88 & 0.87 \\
\hline & \multirow{2}{*}{$\begin{array}{r}10 \text { years }- \text { less than } 15 \\
\text { years }\end{array}$} & \multirow[t]{2}{*}{121} & Arithmetic mean & 2.67 & 2.76 \\
\hline & & & Standard deviation & 0.93 & 0.94 \\
\hline & \multirow[t]{2}{*}{15 years or more } & \multirow[t]{2}{*}{84} & Arithmetic mean & 2.34 & 2.44 \\
\hline & & & Standard deviation & 0.87 & 0.85 \\
\hline & \multirow[t]{2}{*}{ Overall } & \multirow{2}{*}{694} & Arithmetic mean & 2.38 & 2.45 \\
\hline & & & Standard deviation & 0.78 & 0.78 \\
\hline
\end{tabular}

Based on table (6), it appears that there are differences between the respondents' attitudes which can be attributed to (university, job title, and experience). To explore whether those differences are statistically significant or not at the statistical significance level of $(a=0.05)$, the multivariate analysis of variance (MANOVA) was conducted. The results of the latter analysis are presented in table (7) below:

Table (7): The results of the multivariate analysis of variance (MANOVA) for identifying whether there are statistically significant differences between the respondents' attitudes which can be attributed to (university, job title, and experience) or not

\begin{tabular}{|c|c|c|c|c|c|c|}
\hline Variable & Area & Sum of squares & Df & Mean square & F value & Sig. \\
\hline \multirow{2}{*}{$\begin{array}{l}\text { University } \\
\text { Wilks value: } 0.805 \\
\text { Sig.: } 000 \\
\text { F value: } 39.292^{b}\end{array}$} & Educational policies & 47.590 & 2 & 23.795 & 47.086 & 0.000 \\
\hline & Technical education & 74.586 & 2 & 37.293 & 79.264 & 0.000 \\
\hline \multirow{2}{*}{$\begin{array}{l}\text { Job title } \\
\text { Wilks value: } 0.966 \\
\text { Sig.: } 0.807 \\
\text { F value: } 0.502^{b}\end{array}$} & Educational policies & 0.505 & 3 & 0.168 & 0.333 & 0.801 \\
\hline & Technical education & 0.758 & 3 & 0.253 & 0.537 & 0.657 \\
\hline \multirow{2}{*}{$\begin{array}{l}\text { Experience: } \\
\text { Wilks value: } 0.994 \\
\text { Sig.:657 } \\
\text { F value: } 691^{b}\end{array}$} & Educational policies & 1.356 & 3 & 0.452 & 0.894 & 0.444 \\
\hline & Technical education & 1.737 & 3 & 0.579 & 1.231 & 0.298 \\
\hline \multirow[t]{2}{*}{ Error } & Educational policies & 346.165 & 685 & 0.505 & & \\
\hline & Technical education & 322.286 & 685 & 0.470 & & \\
\hline \multirow[t]{2}{*}{ Overall } & Educational policies & 422.438 & 693 & & & \\
\hline & Technical education & 427.166 & 693 & & & \\
\hline
\end{tabular}

Based on table (7), there isn't any statistically significant difference - at the statistical significance level of 
$(\mathrm{a}=0.05)$ - between the respondents' attitudes which can be attributed to (job title, and experience). However, there are statistically significant differences -at the statistical significance level of $(\mathrm{a}=0.05)$ - between the respondents' attitudes which can be attributed to (university) in the (educational policies) and (technical education) areas. To identify the ones whose the differences are for their favor, Scheffe test was conducted. Table (8) presents the results of the latter test

Table (8): the results of Scheffe test to identify the ones whose the differences are for their favor

\begin{tabular}{|c|c|c|c|c|c|c|}
\hline \multirow{2}{*}{\multicolumn{3}{|c|}{ Variable }} & \multicolumn{2}{|c|}{$\begin{array}{l}\text { The (educational } \\
\text { policies) area }\end{array}$} & \multicolumn{2}{|c|}{$\begin{array}{l}\text { The (technical } \\
\text { education) area }\end{array}$} \\
\hline & & & $\begin{array}{l}\text { Arithmetic } \\
\text { mean }\end{array}$ & Sig. & $\begin{array}{l}\text { Arithmetic } \\
\text { mean }\end{array}$ & Sig. \\
\hline \multirow[t]{4}{*}{ University } & \multirow[t]{2}{*}{$\begin{array}{l}\text { Universities located } \\
\text { in the central province }\end{array}$} & $\begin{array}{l}\text { Universities located } \\
\text { in the Southern } \\
\text { province }\end{array}$ & $.6335^{*}$ & 0.00 & $.7104^{*}$ & 0.00 \\
\hline & & $\begin{array}{l}\text { Universities located } \\
\text { in the } \begin{array}{l}\text { Northern } \\
\text { province }\end{array}\end{array}$ & $.5341^{*}$ & 0.00 & $.6949^{*}$ & 0.00 \\
\hline & \multirow{2}{*}{$\begin{array}{l}\text { Universities located } \\
\text { in the Northern } \\
\text { province }\end{array}$} & $\begin{array}{l}\text { Universities located } \\
\text { in the central province }\end{array}$ & & & & \\
\hline & & $\begin{array}{l}\text { Universities located } \\
\text { in the } \begin{array}{l}\text { Southern } \\
\text { province }\end{array}\end{array}$ & 0.0994 & 0.48 & 0.0155 & 0.98 \\
\hline
\end{tabular}

Based on table (8), there are statistically significant differences between the respondents' attitudes which can be attributed to the university in the (educational policies) and (technical education) areas. The latter differences are for the favour of the ones working in the universities located in the Central Province

\section{Discussion}

\section{Discussion related to the first question:}

Q.1. What is the extent of implementing the educational policies that are based on modern trends for improving technical education in Jordanian public universities from the perspective of academic leaders?

\section{The educational policies area:}

It was found that the extent of implementing the educational policies that are based on modern trends for improving technical education in Jordanian public universities is moderate from the perspective of academic leaders in two areas. These areas are: (educational policies and technical education. The latter result may be attributed to having vague policies for regulating and improving the delivery of technical education. Such policies shall hinder the provision of the labor markets with professional technicians. The latter result indicates that there is a need for having reality-based plans for delivering technical education. It may be attributed to the failure of the educational policies in universities in meeting the society's needs. It may be attributed to the lack of attention given by universities for the assessment of performance through developing accreditation regulations. Such lack of attention shall hinder universities from delivering education of high quality. The latter result is consistent with the result concluded by Al-Sahli (2019). The latter researcher found that the effectiveness of educational policies in Saudi universities is moderate.

\section{The technical education area:}

It was found that the extent of implementing the educational policies that are based on modern trends for improving technical education in Jordanian public universities is moderate from the perspective of academic leaders in the technical education area. The latter result is attributed to the failure of educational policies in delivering technical education of high quality. It is attributed to the failure of educational policies in promoting adequate awareness about the significance of technical education. It may be attributed to the failure of educational policies in keeping up with the latest technological developments and attracting highly qualified faculty members for delivering technical education. It may be attributed to the failure of educational policies in attracting highly qualified students. It may be attributed to the failure of universities in creating convenient learning environment for the delivery of technical education.

The latter result may be attributed to the failure of universities in keeping up with the latest developments. It may be attributed to the failure of universities in establishing partnerships with private and public institutions in various sectors. It may be attributed to the failure of universities in providing training courses for the students receiving technical education. It may be attributed to the failure of universities in addressing the challenges facing trainees. It may be attributed to the failure of universities in developing trainees and enabling them to join the labour market. It is consistent with the result concluded by Harfoosh and Harfoosh (2019). The latter researchers found that the role of principals in Palestine in promoting positive attitudes among school students towards technical and vocational education is moderate. 
The latter result is consistent with the result concluded by Abdullah (2017). The latter researcher found that the efficiency of technical and vocational educational programs in Libya is low. He also found that that the number of students who join these programs is low. The latter result is inconsistent with the result concluded by Abu Athrah et al. (2013). The latter researchers found that Palestine Technical College aims at achieving sustainable development because it provides students with skills and information for achieving personal development.

\section{Second: Discussion related to the second question}

Q.2. Is there any statistically significant difference -at the statistical significance level of $(a=0.05)$ - between the respondents' attitudes which can be attributed to (university, job title, or experience)?

It was found that there are statistically significant differences - at the statistical significance level of $(a=0.05)$ between the respondents' attitudes which can be attributed to (university) in the (educational policies) and (technical education) areas. The latter differences are for the favour of the ones working in the universities located in the Central Province. That may be attributed to the fact that the population density in the Central Province is high. It may be attributed to having a great number of universities in the Central Province. It is consistent with the result concluded by Abu Al-Rab (2017). The latter researchers found that there isn't any statistically significant difference -at the statistical significance level of $(\mathrm{a} \leq 0.05)$ - between the respondents' attitudes which can be attributed to experience or job title. The latter result is inconsistent with the result concluded Abu Zainah (2011). The latter researcher found that there are statistically significant differences between the respondents' attitudes which can be attributed to university for the favor of ones working in the universities located in the Southern Province. He found that there are statistically significant differences between the respondents' attitudes which can be attributed to job title. The latter differences are for the favor of (deans). The latter researcher found that there are statistically significant differences between the respondents' attitudes which can be attributed to experience. The latter differences are for the favor of the ones whose experience is greater than 10 years.

\section{Conclusion}

Through analysing data, it was found that the extent of implementing the educational policies that are based on modern trends for improving technical education in Jordanian public universities is moderate from the perspective of academic leaders in two areas. These areas are: (educational policies and technical education). It was found that there isn't any statistically significant difference - at the statistical significance level of $(a=0.05)$ - between the respondents' attitudes which can be attributed to job title or year of experience. It was found that there is a statistically significant difference - at the statistical significance level of $(a=0.05)$ - between the respondents' attitudes which can be attributed to university. The latter difference is for the favor of the ones who work in the universities located in the Central Province.

\section{Recommendations}

In the light of the study's results, the researchers concluded the following:

1- Promoting awareness among leaders of the top administrative levels in public universities about the need for developing the educational policies that aim at improving technical education

2-Promoting attention about the significance of technical education by media channels

3-Conducting more studies about technical education and searching for methods that develop technical education 4-Making changes to the educational policies that aim at developing technical education. The researchers recommend conducting studies about the policies that aim at developing technical education. They recommend conducting similar studies with targeting other variables.

\section{References}

References Published in Arabic language:

Abu Al-Rab, Ahmad Mohsen (2017). A future vision for the development of technical education in Palestinian universities in accordance with contemporary global experiences. Unpublished $\mathrm{PhD}$ dissertation. The University of Jordan. Amman. Jordan

Abu Qaren, Al-Sara'li (2012). The development of an Arab plan for developing technical and vocational education in accordance with global trends: A project for developing education development plan in the Arab World. The Arab League Educational, Cultural and Scientific Organization

Abu Zainah, Tayseer (2011). The development of excellence criteria for technical education in intermediate university colleges in Jordan. Dirasat Journal: Educational Sciences. 38(2), 2471-2506

Ismail, Suad (1989). The educational policies in the eastern part of the Arab world. Amman. The Arab Thought Forum

Bashyawa, Hasan (2013). Modernism in the educational policies and the use of technologies in the Arab countries: fear and necessity. The Journal of the Faculty of Education. Ha'el University. The Kingdom of Saudi Arabia.

Battah, Ahmad (2018). Issues and views. Amman. Dar Al-Shorooq

Battah, Ahmad (2020). The policies of educational systems: from a comprehensive perspective. Dar Wael, Amman, 
Jordan

Al-Btoush, Bassam (2019). Al-Hussein Technical University: Various and innovative streams in technical and applied education: An article published on the website of Al-Hussein Technical University. Available on the following link: https://www.htu.edu.jo/node/179

Harfoosh, Yousif and Harfoosh, Noor (2019). The role of technical and vocational education in fighting against unemployment from the perspective of students' parents: Visions, and thoughts on significant issues related to technical and vocational education. The Proceedings of the Fourth International Annual Conference. This conference is held by the Jordanian Association for Educational Sciences in cooperation with Aqaba University of Technology. Amman. Dar Jareer

Al- Zawba'I, Obaid Mahmoud, and Al-Janabi, Imad Hazim (2017). The development of curricula for technical education and vocational training: Cairo. Al-Maktab Al-Arabo Lilma'aref

Zeedan, Osama (2012). A proposed vision for having a leadership that makes effective changes in universities. The Journal of the Faculty of Education in Suez University. 5(4), 153-195

AL-Suheimat, Ahmad (2003). An analytical study for educational policies in accordance with social, economic, and political changes and the impact of those changes on educational development in Jordan. Unpublished PhD dissertation. Amman Arab University. Amman. Jordan

Al-Sahli, Mohammad bin Ali (2019). The development of educational policies in Saudi universities in accordance with the requirements of the competitiveness. A proposed strategy. Unpublished PhD dissertation. King Saud University. Reyad.

Al- Twaisi, Ahmad (2013). The proposed solution for improving the attitudes of the society's members towards technical and vocational education from the perspective of Jordan. Dirasat Journal: Educational Sciences. 40(2). 1510-1493

Abed Al-Ghani, Fadel and Abed Al-Qader, Ahmad Abdullah (2017). The reailty of technical education in Sudan. The Journal of Educational Sciences. 1(18). 79-94

Abdullah, Najat (2017). A proposed vision for developing technical and vocational education in Libya. The Journal of the Faculty of Education. University of Benghazi. 1(4), 58-35

Al-Qarni, Norah (2017). The reality of managing a training vocational and technical educational program in the public vocational training centers in the Kingdom of Saudi Arabia. The Proceedings of the Fourth International Annual Conference. This conference is held by the Jordanian Association for Educational Sciences in cooperation with Aqaba University of Technology. Amman. Dar Jareer

The Economic and Social Council (2017). The reality of technical and vocational education and training in Jordan. Retrieved on 3-9-2020. Available on the following link: http://www.esc.jo/Documents/04dc322d-b0024de0-b3b8-f7a7f386eef7.pdf

Al- Mutairi, Nayef; Al-Slaihat, Rawan and Flooh, Rawan (2019). The role of vocational and technical education in meeting the requirements of development in Jordan from the perspective of experts and specialists. The Proceedings of the Fourth International Annual Conference. This conference is held by the Jordanian Association for Educational Sciences in cooperation with Aqaba University of Technology. Amman. Dar Jareer

The Ministry of Education (2012). Developing a project for training vocational education teachers who teach fifth grade students. Retrieved on 2-9-2020. Available on the following link: http://webcache.googleusercontent.com/search

The United Nations Educational, Scientific and Cultural Organization (UNESCO) (2009). The achievement of higher educational institutions in the Arab World and the challenges facing these institutions. The Arab Regional Conference on Higher Education. Cairo. 30. May- June

\section{References Published in English language:}

Barba-Sánchez, Virginia \& Atienza-Sahuquillo, Carlos (2018). "Entrepreneurial Intention Among Engineering Students: The Role Of Entrepreneurship Education," European Research on Management and Business Economics (ERMBE), 24(1): 53-61..

UNISCO (2009). Current Issuer and Trends in Technical and Vocational Education, UNEVOC Studies in the Technical and Vocational Education, $\mathrm{N}(8)$.

Sekran, Uma (2003). Research Method for Business‘ (4rd ed.). USA: John Wiley. 